International Journal of Instruction

e-ISSN: 1308-1470 • www.e-iji.net

Article submission code:

20200607134509

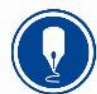

October $2021 \bullet$ Vol.14, No.4

p-ISSN: 1694-609X

pp. 791-808

Received: 07/06/2020

Revision: 24/04/2021
Accepted: 19/05/2021

OnlineFirst: 02/09/2021

\title{
Using a Cognitive Style-Based Learning Strategy to Improve Students' Environmental Knowledge and Scientific Literacy
}

\section{Arif Sholahuddin}

Assoc. Prof. Dr., Faculty of Education, Universitas Lambung Mangkurat, Banjarmasin, Indonesia, arif.science.edu@ulm.ac.id

\section{Eko Susilowati}

Dr. Faculty of Education Universitas Lambung Mangkurat Banjarmasin Indonesia, titis_pfis@ulm.ac.id

\section{Binar Kurnia Prahani}

Dr. Faculty of Mathematics and Science Universitas Negeri Surabaya Indonesia, binarprahani@unesa.ac.id

\section{Erman Erman}

Prof. Dr., Faculty of Mathematics and Science Universitas Negeri Surabaya Indonesia, erman@unesa.ac.id

Scientific literacy is the ability to explain phenomena and solve problems using scientific knowledge. Despite being an important factor in the scientific and technological advancement of society, students worldwide struggle to attain the skills necessary to demonstrate competency in scientif literacy. This study examines the capacity for a cognitive style-based learning strategy (CSBLS) to improving students' environmental knowledge and scientific literacy. 55 students from two Indonesian state junior high schools (SMPN) participated in the research; 30 students from SMPN 6, Banjarmasin and 25 students from SMPN 21, Banjarmasin. The CSBLS was applied during six classroom meetings over a three week period using a group pre-test and post-test on the topic of environmental pollution. The study concluded that the CSBLS was able to improve students' environmental knowledge and scientific literacy. In addition, the learning strategy supported students different cognitive styles (Field Independent/FI and Field Dependent/FD, although scaffolding was still needed for tasks that required more complex thinking such as scientific literacy, particularly for FD. This research indicates that a CSBLS has the potential to improve students' environmental knowledge and scientific literacy throughout the learning process.

Keywords: cognitive style, learning strategy, scientific literacy, environmental pollution, field independent, field dependent

Citation: Sholahuddin, A., Susilowati, E., Prahani, B. K., \& Erman, E. (2021). Using a cognitive stylebased learning strategy to improve students' environmental knowledge and scientific literacy. International Journal of Instruction, 14(4), 791-808. https://doi.org/10.29333/iji.2021.14445a 


\section{INTRODUCTION}

Scientific literacy is the ability to apply scientific knowledge to explain phenomena and to solve nature problems that includes human interactions (Dani, 2009; OECD, 2019, Rahayu, 2017). Knowledge and literacy are two variables that cannot be separated. Achieving competency in scientific literacy is a major challenge faced by students worldwide; a situation that is concerning for teachers as scientific literacy can determine the role students have in future science, technology, and economic development in their society.

Between 2009 to 2018,the International Student Assessment Program (PISA) Report showed that the scientific literacy of Indonesian students aged between 15 and 16 years ranked in the bottom ten OECD countries with a science ability score below average, a result supported by Fakhriyah, Masfuah, Roysa, Rusilowati, and Rahayu (2017). The 2019 PISA report (OECD, 2019), showed 78\% of students from participating countries achieved a score of between level 2 and 3, compared to $40 \%$ of Indonesia students reaching that level with $60 \%$ of students achieving below level 2 . Students were unable to relate daily content and basic procedural knowledge to identify an appropriate scientific explanation, interpret data, draw a valid conclusion or identify the question in a simple experimental design. This result indicates that students have limited scientific knowledge and that they can only apply it in some situations. Results also point to the need for the quality of science learning to be improved.

It would appear that low scientific literacy is due to the disconnect between learning processes in schools, that rely on lectures delivered through conceptual explanations and teacher-centered examples, and the PISA evaluation indicators that favour expository strategies (Ardianto and Rubini, 2016). Typically, learning in Indonesian schools begins with an explanation of theory, with examples provided by the teacher, and ends with the students completing exercises. The process does not involve higher order thinking skills such as contextualizing environmental problem solving, and it rarely uses cooperative or collaborative discussion strategies. Learning is content knowledge oriented, which requires students' to simply master basic concepts, thereby contributing to low scientific literacy. Teachers' limited knowledge and scientific education skills, and a limited ability to employ suitable learning strategies also contribute to the low standing of Indonesian students science literacy results (Dragos \& Mih, 2015; McBride, Zollman, \& Rebello, 2010). Science learning requires a strategy-based inquiry approach to achieve knowledge, process and problem solving skills, and to enable scientific literacy and positive attitudes towards science to be developed (Afriana, Permanasari \& Fitriani, 2016; Aktamişl1, Hiğde, \& Özden, 2016; Athuman, 2017; Ardianto \& Rubini, 2016; Ergül, Şımşeklı, Çaliş, Özdılek, Göçmençelebı, \& Şanli, 2011; Wahyuni, Indrawati, Sudarti \& Suana, 2017).

Cognitive style-based learning strategies (CSBLS) were designed by Sholahuddin, Yuanita \& Kardi (2014), and the effectiveness of the approach in developing science process skills and problem solving was demonstrated as part of a scientific literacy program in an elementary school (Sholahuddin, 2018; Sholahuddin, Yuanita, Supardi, Prahani, 2020). A previous study showed that, due to the inability to identify problems, 
secondary school students tended to use strategies that were limited to addressing lower order skills such as managing resources and regulating attention and perception. Few students used more complex strategies, such as elaboration, analysis and manipulation (Rubenstein, Callan, Neumeister, Ridgley, 2020). Although Problem-Based Learning (PBL) could facilitate higher-order thinking and problem solving skills, these learning strategies are rarely used by teachers due to the difficulty they have in adapting to the requirements of a PBL learning process (Sugano \& Nabua, 2020).

PBL emphasizes process over knowledge (Drake \& Long, 2009; Burris and B. L. Garton, 2007; Stepien, Gallagher, and Workman, 1993). In order to overcome what is considered a weakness in the PBL process, the CSBLS was developed to facilitate student understanding from concrete to formal thinking development by considering differences in cognitive styles. Cognitive styles influence how students' assimilate and process information, their learning achievement, and their problem solving skills (Ratumanan, 2003; Ardana, 2008; Stamovlasis, Tsitsipis, \& Papagergeou, 2010; Tinajero, \& Paramo, 1997; Tinajero, Lemos, Araujo, Ferraces, and Paramo, 2012). The planning strategies of learning mediate the influence of cognitive style on achievement (Chen, Liou \& Chen, 2019; Tinajero et al., 2012). Threfore, to obtain optimal learning and achievement, it is important to accommodate a learner's cognitive style within each learning strategy.

Cognitive style is an individual characteristic of consistent information processing such as perceiving, organizing, analyzing and solving problems (Armstrong, Peterson \& Rayner, 2012; Davis, 2006; Wang, 2014). Cognitive style shows how learners process information. Therefore, individuals with different styles can successfully learn, assuming they use a suitable strategy. These styles are classified as Field Independent (FI) and Field Dependent (FD), both of which have different attributes according to the way information is processed. Students who demonstrate FI characteristics are analytic, competitive, independent, and individual. They also develop goals and objectives, are strategic and intrinsically motivated and they provide self-reinforcement. Furthermore, they are able to separate elements and background from a related context, and tend to solve problems using logic. They do, however, present with weak social skills and prefer learning in a structured and organized manner. Students with FD cognitive styles present with opposite characteristics to FI students, therefore, learning strategies must accommodate individual characteristic.

In previous research, the CSBLS has proved to be valid and effective in enhancing several scientific literacy competencies such as science knowledge, and process and problem solving skills in elementary school students (Sholahuddin, Yuanita \& Kardi, 2014; Sholahuddin \& Yuanita \& Kardi, 2016). However, junior high school students with the same cognitive developmental levels have not been tested. Therefore, this study analyzes the capacity for the CSBLS to improve junior high school students' knowledge and scientific literacy and its ability in optimally facilitating learning for students with different cognitive styles. 


\section{METHOD}

This research was designed to use one group pre-test and post-test (Fraenkel, Wallen, \& Hyun, 2012). Particupants were aged between 13 and 14 years old, and the CSBLS was applied during learning about environmental pollution over a period of 3 weeks or 6 class meetings. The state junior high schools (i.e. SMPN) involved in this study were SMPN 6 and SMPN 21 Banjarmasin. These schools represent very good and good qualified due to Indonesian National accreditation respectively. The random sample from SMPN 6 was represented by 30 students consisting of 12 FI and 18 FD, while SMPN 21 was represented by 25 students with 11 FI and 14 FD.

The stages of CSBLS learning Strategy is presented at Table 1.

Table 1

The stages of CSBLS learning Strategy

\begin{tabular}{|c|c|c|}
\hline No & Learning Steps & Learning Activities \\
\hline 1 & Attention & $\begin{array}{l}\text { Teachers focus the students on learning through delivery of objectives, } \\
\text { apperception, connected prerequisite and the knowledge being studied }\end{array}$ \\
\hline 2 & $\begin{array}{l}\text { Understanding } \\
\text { the Problem }\end{array}$ & $\begin{array}{l}\text { Teachers create a problem, and ask the students to understand it and follow the } \\
\text { instructions on the worksheet. }\end{array}$ \\
\hline 3 & Exploration & $\begin{array}{l}\text { Students are encouraged and helped to gather the necessary information, conduct } \\
\text { the simple experiment or observation to solve the problem. They have to formulate a } \\
\text { hypothesis or prediction, seek information from various sources, or perform } \\
\text { observations to gather data, interpret the data, draw conclusions, and evaluate the } \\
\text { solution. }\end{array}$ \\
\hline 4 & Sharing & $\begin{array}{l}\text { Teachers facilitate and provide feedback to students by sharing their result or ideas } \\
\text { between groups. }\end{array}$ \\
\hline 5 & Game & $\begin{array}{l}\text { Teachers deepen and strengthen the students' content knowledge by engaging them } \\
\text { in rehearsal games. }\end{array}$ \\
\hline 6 & Assessment & Teachers evaluate the students' knowledge and problem solving abilities \\
\hline 7 & Individual Task & Teachers engage the students with problem solving tasks as a learning enrichment. \\
\hline
\end{tabular}
Sholahuddin, Yuanita, \& Kardi (2014); Sholahuddin (2018)

The CSBLS was used to scaffold scientific problem solving throughout the seven learning steps outlined above by being applied in groups of 5-6 students who used a worksheet guide based on CSBLS stages to solve problems related to environmental pollution. Teachers facilitated the learning by providing assistance and scaffolding according to student needs. The CSBLS approach involved several analytical processes, therefore, the teacher's attention needed to be focused on students with FD learning styles who generally do not do well with this type of activity. On the other hand, students with FI generally dislike collaborative activities, therefore, teachers also needed to ensure those students were fully engage in collaborative activities.

The learning materials used in this study included lesson plans, student worksheets, and laboratory tools. A cognitive style test, knowledge test and a scientific literacy test instrument were also used to measure many of the indicators that the process aimed to addressed. A cognitive style evaluation was conducted using the Group Embedded Figures Test (Ardana, 2008; Mefoh, Nwoke, Chukwuorji, Chijioke, 2017; Witkin, Oltman, Raskin, \& Karp, 1971), which is a timed test that requires the taker to find a 
certain simple image from complex images. This test have a construct validity of 0.82 and a test-retest (3-year period) reliability coefficient of 0.89 (Witkin et al., 1971). The test also provides two items as questions and answers examples which are then divided into three. The first part consisted of 7 test items to be answered in 2 mins, and was not graded. The second and third parts were graded and consisted of 9 items each to be completed within 5 minutes per part. Therefore, students with 0-11 score were categorized as having FD cognitive style, while those with 12-18 were considered to be FI. The environmental pollution knowledge test consisted of 25 items of multiple choices questions with varied cognitive levels from $\mathrm{C} 1$ (remembering) to $\mathrm{C} 4$ (analyzing). The scientific literacy test also consisted of 25 items of multiple choices questions to assess identifying scientific problems, explaining phenomena, and solving daily problems with evidence competencies. In addition, both the knowledge and scientific literacy test were valid with an average validity index (Aikens' V) of 0.80 and 0.85 respectively. Both instruments were also reliable with a KR20 reliability index of 0.78 and 0.74 respectively.

The capacity for CSBLS to improve student knowledge and scientific literacy was analyzed in relation to environmental pollution subject matter according to the following scoring criteria: very high $=90-100$, high $=70-89$, moderate $=50-69$, and low $=0-49$. The learning strategy is said to increase environmental knowledge and scientific literacy if they increase minimally in the moderate category or with an n-gain score between 0.3 to 0.7 . As a prerequisite for analysis, the data were also analyzed for their homogeneity and normality using the Lavene test and the Kolmogorov-Smirn with $\alpha=0.05$ respectively.

\section{FINDINGS}

Teachers from two different participating schools provided qualitative data by implementing the learning process in accordance with the characteristics of the CSBLS. Teachers needed to adapt at the beginning of the process when considering students' cognitive styles. Observations during the learning process, when the CSBLS was being applied at SMPN 6 and SMPN 21 for over three weeks, showed that teachers were able to adapt. Students' activities in both participating schools scored in the very good and good categories respectively.

The participating students also needed to adapt at the beginning of the research project as they initially waited for the teacher to provide instructions on when to start learning. However, they were able to follow the CSBLS in subsequent lessons once the process was explained. If using the process in the future, improvements need to be undertaken to support the students' capacity to explain to other students, express their ideas and seek information from various sources.

\section{Enviromnental Pollution Knowledge}

Figure 1 shows student knowledge of enviromnental pollution scores based on indicators from the two participating schools after applying the CSBLS. Knowledge (K) description indicators are 1. Explaining the definition of environmental pollution, 2. Explaining an understanding of water pollution, 3. Cleaning up the factors causing water 
pollution, 4. Explaining the impact of water pollution 5. Determining how to overcome water pollution, 6. Analyzing factors causing water pollution, 7. Explaining the definition of air pollution, 8. Mentioning the factors causing air pollution, 9. Explaining the effects of air pollution, 10. Determining how to reduce air pollution, 11. Analyzing the factors causing air pollution, 12. Explaining the definition of soil pollution, 13. Stating the factors causing soil pollution, 14. Explaining the impact of soil pollution, 15. Determining how to overcome soil pollution, 15. Analyzing the factors causing soil pollution.

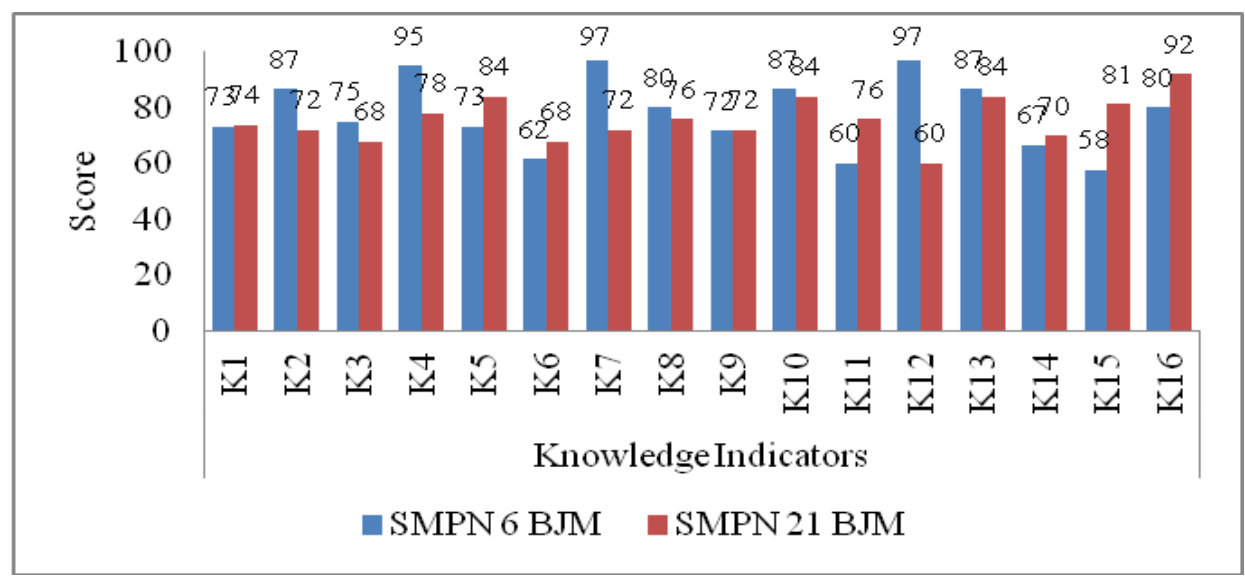

Figure 1

Students' knowledge of environmental pollution

Table 2 shows an overview of students' scores before and after learning the environmental pollution topic using the CSBLS.

Table 2

Learning outcome of science knowledge

\begin{tabular}{lll}
\hline \multirow{2}{*}{ Elements } & Schools/Score & \\
\cline { 2 - 3 } & SMPN 6 & SMPN 21 \\
\hline Pre-test & 43.47 & 53.92 \\
\hline Post-test & 75.87 & 75.20 \\
\hline FD & 73.11 & 76.57 \\
\hline FI & 80 & 73.45 \\
\hline N-Gain & 0.58 & 0.45 \\
\hline
\end{tabular}

The homogeneity of students' knowledge variance data was tested with the Lavene test ( $\mathrm{df}=53, \alpha=0.05)$, and a significant value of $0.132>0.05$ was obtained, which was then declared homogeneous. The pre- and post-test data of the two school samples was tested for normality using the Kolmogorov-Smirn and showed a significant value $>0.05$ which means data were normally distributed. The independentt test outcomes $(\mathrm{df}=53, \alpha$ $=0.05$ ) also has significant value (2-tailed) of $0.089>0.05$ (Table 3), meaning there is no difference in knowledge between students of SMPN 6 and those of SMPN 21 Banjarmasin. 
Table 3

Independent $t$ test of science knowledge between students of SMPN 6 and SMPN 21 Banjarmasin

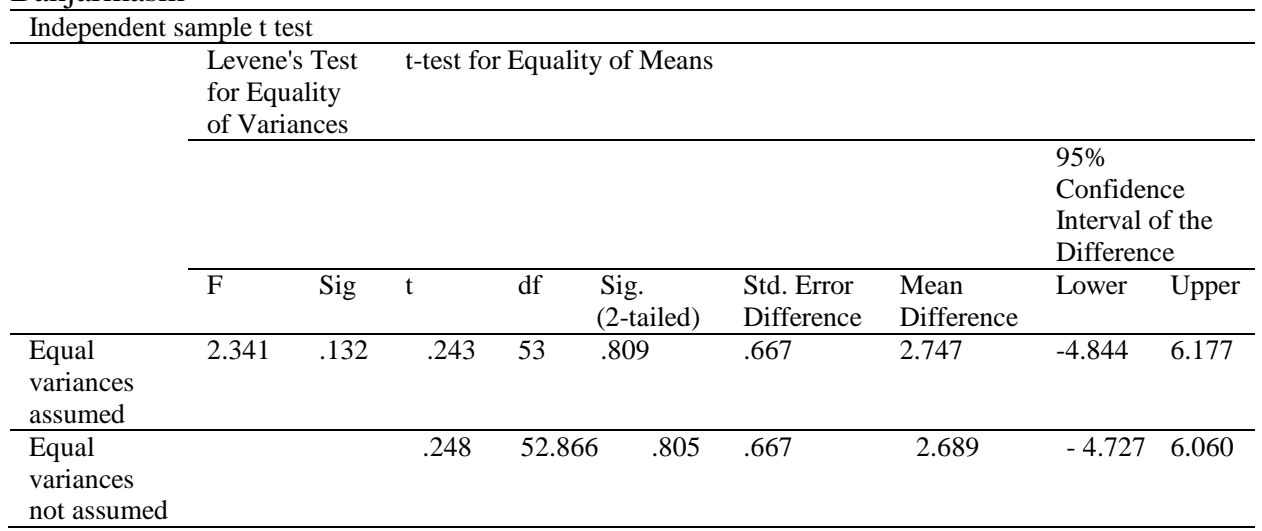

\section{Scientific literacy}

Figure 2 shows students' scientific literacy scores after learning by the CSBLS.

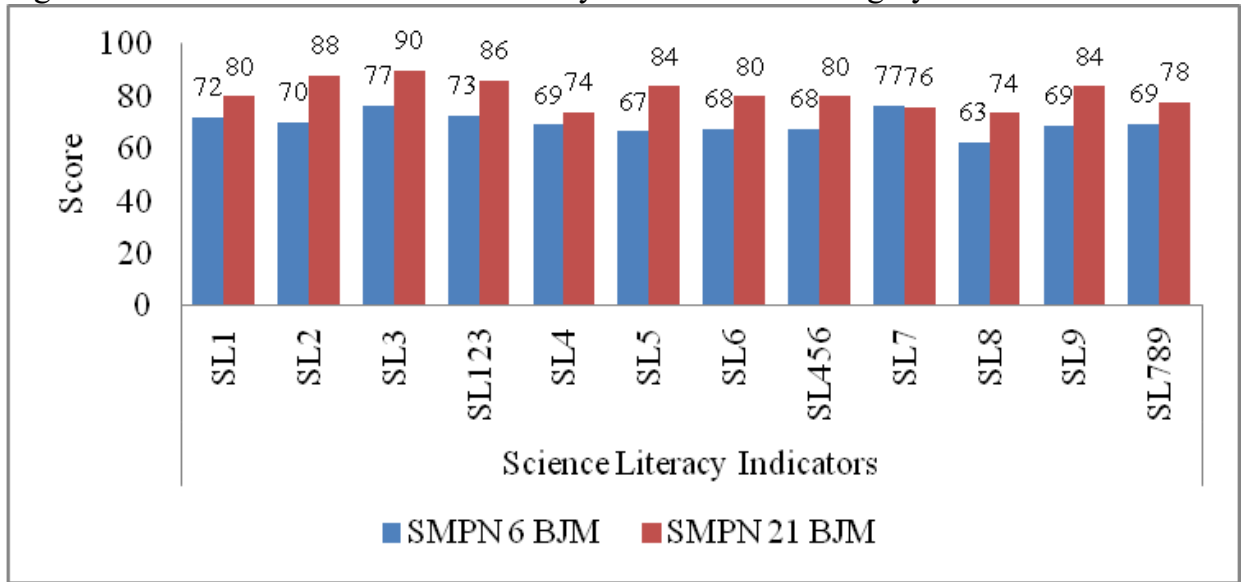

Figure 2

Students' scientific literacy

Scientific literacy competencies are:

SL123 Explaining scientific phenomena

Scientific literacy indicators:

SL1: Remembering and applying appropriate scientific knowledge

SL2: Making and justifying predictions

SL3: Offering explanatory hypotheses

SL345 Evaluating and designing scientific investigations 
Scientific literacy indicators:

SL4: Identifying the problem explored in a given scientific study.

SL5: Distinguishing problems that allow for scientific investigation

SL6: Proposing a way to scientifically explore the problem

SL789 scientifically interpreting data and evidence

Scientific literacy indicators:

SL7: Transforming data from one representation to another

SL8: Analyzing and interpreting data, drawing interesting conclusions

SL9: Evaluating scientific arguments and evidence from different sources

Table 4 shows the students' scientific literacy scores before and after learning through the CSBLS.

Table 4

Score of Scientific literacy

\begin{tabular}{lll}
\hline \multirow{2}{*}{ Elements } & School/Score & \\
\cline { 2 - 3 } & SMPN 6 & SMPN 21 \\
\hline Pre-test & 51.73 & 55.60 \\
Post-test & 69.06 & 79.20 \\
FD & 67.33 & 77.29 \\
FI & 71.67 & 81.64 \\
N-gain & 0.33 & 0.53 \\
\hline
\end{tabular}

The student literacy data outcomes were tested for variance homogeneity with the Lavene test $(\mathrm{df}=53, \alpha=0.05)$, and a significant value of $0.230>0.05$ was obtained, which means the data is homogeneous. Furthermore, the pre and post-test data from the two school samples also tested for normality, using the Kolmogorov-Smirn, showed a significant value $>0.05$, which means the data were normally distributed. The independent test outcomes ( $\mathrm{df}=53, \alpha=0.05)$ also have a significant value (2-tailed) of $0.002<0.05$ (Table 5), meaning there are differences in scientific literacy between students of SMPN 6 and those of SMPN 21 Banjarmasin.

Table 5

Independent $t$ test of scientific literacy between students of SMPN 6 and SMPN 21 Banjarmasin

\begin{tabular}{|c|c|c|c|c|c|c|c|c|c|}
\hline \multicolumn{10}{|c|}{ Independent sample $\mathrm{t}$ test } \\
\hline & \multicolumn{2}{|c|}{$\begin{array}{l}\text { Levene's Test } \\
\text { for Equality of } \\
\text { Variances } \\
\end{array}$} & \multicolumn{7}{|c|}{ t-test for Equality of Means } \\
\hline & & & & & & & & \multicolumn{2}{|c|}{$\begin{array}{l}95 \% \text { Confidence } \\
\text { Interval of the } \\
\text { Difference }\end{array}$} \\
\hline & $\bar{F}$ & Sig & $\mathrm{t}$ & df & $\begin{array}{l}\text { Sig. } \\
\text { (2-tailed) }\end{array}$ & $\begin{array}{l}\text { Std. Error } \\
\text { Difference }\end{array}$ & $\begin{array}{l}\text { Mean } \\
\text { Difference }\end{array}$ & Lower & Upper \\
\hline $\begin{array}{l}\text { Equal variances } \\
\text { assumed }\end{array}$ & 1.476 & .230 & -3.264 & 53 & .002 & -10.133 & 3.105 & -16.360 & -3.906 \\
\hline $\begin{array}{l}\text { Equal variances } \\
\text { not assumed }\end{array}$ & & & -3.345 & 52.631 & .002 & -10.133 & 3.029 & -16.211 & -4.056 \\
\hline
\end{tabular}




\section{DISCUSSION}

\section{Ability the CSBLS to Increase Environmental Knowledge and Literacy}

The two participating classes scored in the high category for environmental knowledge (Table 1). This indicates that the CSBLS was effective for learning science concepts related to environmental pollution. The same environmental knowledge was recorded between students of SMPN 6 and SMPN 21 Banjarmasin after learning with the CSBLS strategy, according to independent $t$ test (Table 2). N-gain score indicates that the CSBLS increased students' environmental pollution knowledge of both participating schools in the moderate category (Table 3). Results indicate that the strategy can effectively improve students' environmental pollution knowledge in different school environments. Understanding of discipline-specific information is an important component in building scientific literacy (Karademir \& Ulucinar, 2017; Klucevsek, 2017).

The CSBLS was designed to scaffold knowledge acquisition and student problem solving skills as important elements of scientific literacy (Sholahuddin, Yuanita \& Kardi, 2014; Sholahuddin, 2018). The results (Figure 2 and Table 3) indicate that the scientific literacy of both participating schools increased by a moderate category after engaging in science learning with the CSBLS (Table 4). However, according to the independent test students from both schools performed differently (Table 4). Students from SMPN 6 developed better scientific literacy skills than SMPN 21 Banjarmasin. According to national school accreditation, SMPN 21 already had a lower qualification than SMPN 6, therefore, it appears that school qualification is not a determining factor of students' success against the outcomes. A more important factor is how the learning outcomes, using CSBLS, is implementated in classroom. The CSBLS can strengthening a student's scientific literacy withouth considering their school qualification.

An important finding of this study is that CSBLS can facilitate junior high school students' mastery of environmental knowledge and enable them to achieve scientific literacy, regardless of their school's accreditation level. These results reinforce previous research by Sholahuddin (2018) and Sholahuddin, Yuanita, Supardi and Prahani (2020) that demonstrated how differences in school levels did not affect science process skills or students' problem solving abilities when the learning process applied CSBLS in the classroom.

The school level describes the ability of a school to provide quality education based on national education standards which include content, processes, educator and educational administration, management, infrastructure, financing, graduates and evaluation standards (Permendikbud RI, 2018). The school level is a holistic and comprehensive variable of educational management that can significantly influence the quality of administration, teacher performance and student learning achievement of secondary school students (Khafid \& Barokah, 2006; Siregar 2018; Zulnika, 2017). Accreditation provides educational institutions with a comprehensive framework for continually improving the quality of educational programs and student achievement (Blouin \& Tekian, 2018; Volkwein, Lattuca, Harper \& Domingo, 2007). This study demonstrated 
that the influence of differences in culture and school quality to science learning can be eliminated by implementing the CSBLS.

Implementation of the CSBLS in the classroom was supported by learning tools such as lesson plans and a student worksheet that supported the implementation of learning stages and helped strengthen students' knowledge and scientific literacy. As a measure of scientific literacy, students were provided with real-world problems so that they could explain phenomena or solve problems scientifically by applying their knowledge. In addition to expressing their knowledge, students were required to use their knowledge to analyze and interpret data or facts provided by the real-world scenario. The following some examples of how student scientific literacy was measured.

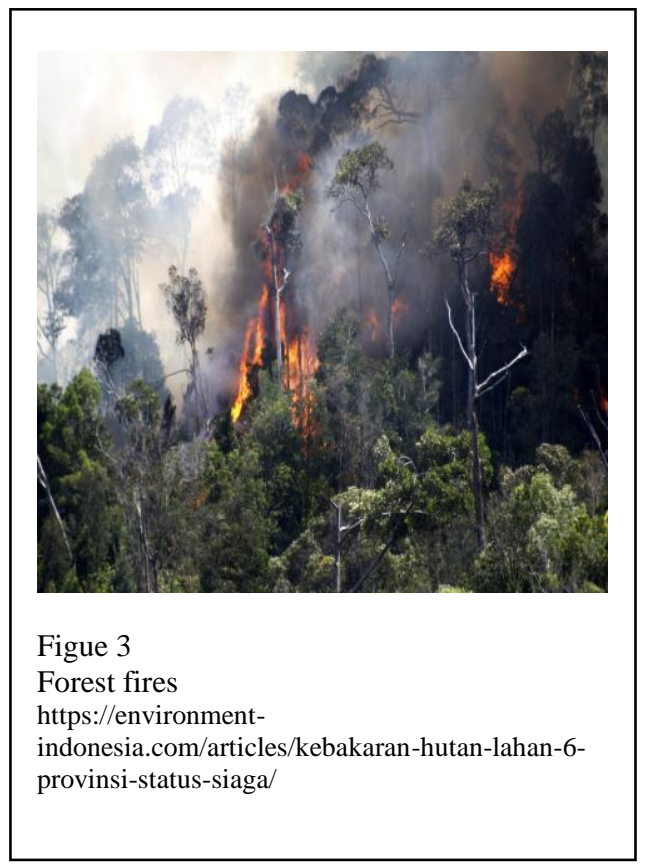

Article:

"Forests are the important ecosystems for living things. Forests are called the lungs of the world because they provide the most oxygen that all living things need. However, during the dry season forest fires often occur either accidentally or people burn forests intentionally to open new plantation land without regard to the effects on the ecosystem. Forest fires cause many plants to die and animals have no food and place to live. Forest fires also produce smoke and carbon dioxide $\left(\mathrm{CO}_{2}\right)$ and other gases so that will reduce their ability to store carbon, water and oxygen. Forest fires cause damage to the ecosystem. While the smoke produced will affect to human activity and health seriously".

Analyzing and interpreting data/facts

1. Forest fires can cause global warming. Based on the article above, explain why forest fires can cause global warming ....

A. Because forest fires can produce smoke, $\mathrm{CO}_{2}$, and other gases that will produce greenhouse gas

B. Because forest fires can result in land subsidence due to greenhouse gas emissions

C. Because forest fires produce more oxygen and have an impact on global warming 
D. Because forest fires produce bare forests and residual ash from fires resulting in global warming

\section{Identifying problems}

2. From the article above, the following statements are the impact of forest fires on environmental damage, except ....

A.Loss of species, namely various flora and fauna.

B. Declining water resources as an impact of the loss of forest's ability in absorbing and storing rainwater.

C.Increasing natural disasters such as floods, landslides, and drought due to disruption of the ecological function of forests.

D.Increased oxygen in the environment as increasing photosynthesis that use carbon dioxide produced.

\section{Ability the CSBLS to Facilitate Students' Cognitive Styles}

Consideration of a student's cognitive style is an important characteristic of the CSBLS which determines how the reaction principle is applied in learning and relates to how the teacher guides and responds to student learning. According to the findings in Tabel 3, students who are field independent (FI) achieve better literacy outcomes than those who are field dependent (FD), although that was not the case for environmental knowledge. The similarity in environmental knowledge between FD and FI students indicates that CSBLS could facilitate the differences in the students' cognitive styles and psychological aspects such as attention skills (Tinajero \& Paramo, 1997), perceptual skills (Zhang, 2010; Yan, 2010) and spatial ability (Hanifah, Juniati \& Siswono, 2018) which contribute to cognitive abilities. Psychological aspects associated with cognitive style influenced the students' ability to analyze and solve the problems. Observation over the learning periods showed that teachers had a critical role in facilitating learning for students with different cognitive styles so that all the students could carry out activities according to the requirements of the learning strategy.

The scientific literacy of a learner with FI is better than a FD learner which means FI students can explain facts and solve environmental problems. However, scientific literacy competence requires additional critical and analytical thinking to explore problems, apply knowledge, offer hypotheses to interpret scientific phenomena, make and justify predictions according to phenomena scientifically, draw conclusions correctly, analyze data precisely, identify and differentiate problems that allows scientific investigation. According to the research indicators, students need to apply better analytical skills to explain facts so as to find solutions to problems. A previous study by Mefoh, Nwoke, Chukwuorji, Chijioke (2017) found that FI students tend to be better than FD students in tasks that require higher order thinking, therefore, teacher scaffolding is essential for FD students to achieve science literacy skills (Sholahuddin, 2018). This research demonstrated how teachers can provided optimal learning conditions for FD students during the CSBLS implementation phase. 
FD and FI styles are represented by capabilities that require visual separation, that is, they are related to a person's perceptual competence (Zhang, 2010; Yan, 2010; Boccia, Piccardi, and Marco, 2016). The FI students tend to have better a perceptual ability, hence, they clearly analyze and find solutions to problems. Pezzuti, Artistico, Chirumbolo, Picone and Dowd (2014) state that problem solving is influenced by cognitive style, and mediated by an ability to think logically. Learning approaches and appropriate classroom management strategies affect scientific literacy levels (Komek, Yagiz, \& Kurt, 2015). Therefore, a student's problem-solving ability as part of scientific literacy competency is continually improved by a learning process that focuses on developing thinking abilities that involve connecting content, process, and product knowledge to solving real-world problems (Vidergor, Givon \& Mendel, 2019).

The accommodation of cognitive styles in the CSBLS is an effort to facilitate the differences in the way students process information by scaffolding learning so that each student learns in an optimal manner. Previous studies report that the use of scaffolding in the form of three levels of inquiry (structured, guided and free inquiry) can improve competencies such as students' scientific reasoning skills (Yanto, Subali, \& Suyanto, 2019), science processing skills (Hardianti \& Kuswanto, 2017; Solahuddin \& Shadriyah, 2017), cognitive skills, procedural skills, critical thinking, scientific concept understanding and motivation (Artayasa, Susilo, Lestari, \& Indriwati, 2018; Zion \& Mendelovici, 2012). Malacapay (2019), reported that scaffolding in accordance with students' learning styles could improve their learning outcomes. Both visual and auditory learners learned best when the teacher used audio-visual presentations while kinesthetic learners learned best when learning was applied to real objects. Sholahuddin, Yuanita and Supardi (2018) reported that the CSBLS also resulted in nurturance effects in the form of social skills and character. Therefore, long-term use of the CSBLS is expected to improve students' scientific literacy as one solution for improving learning quality in order to raise the level of scientific literacy worldwide.

In order to achieve that goal, CSBLS learning processes such as explaining concepts/ideas to other students, expressing ideas and seeking information from various sources, need to be optimized. This requires new learner habits to be formed to conteract the common experience students have in a teacher-centered learning environment that has created passive learners. Further research is needed to reveal other factors that might impact on student learning outcomes such as the teaching material, elearning platforms, multiple intelligences and the impact they have on the implementation of various topics in science. It would also be necessary to conduct the CSBLS trials with a broader sample in order to evaluate its impact on knowledge and scientific literacy due to differences in student characteristics and teacher backgrounds as well as to evaluate the effects of social skills and character.

Based on the above findings, students' scientific knowledge and literacy was improved by using the CSBLS. Previous studies, including this study ,tend to show that students with a FI cognitive style perform better than FD students in tasks involving high level cognition., The findings of this study provide further challenges whether the CSBLS is able to facilitate the achievement of equal literacy competencies for all students. 


\section{CONCLUSION}

Both teachers and students of the participating schools implemented the science learning in accordance with characteristics of the cognitive style-based learning strategy (CSBLS) despite the strategy being relatively new to most science teachers. Most teachers were equally challenged by the need to facilitate students with different cognitive styles over the course of the research. The study found that students' environmental knowledge and scientific literacy competences improved after learning by using the CSBLS. The students' environmental knowledge scored in the high category in both participating schools. The scientific literacy of SMPN 21 students were significantly better than SMPN 6 Banjarmasin which means that school qualification is not a determining factor of students' learning outcomes. The CSBLS was able to support students with different cognitive learning styles in which students with field independent (FI) having the same environmental knowledge as students with a field dependent (FD) cognitive style. Although FI students had a better literacy than those with field dependent (FD) one in both participating schools. In conclusion, the CSBLS was able to improve students' environmental knowledge and scientific literacy. It supported students with different cognitive styles, although it is recognized that scaffolding is needed for tasks that require a more complex thinking level, particularly for FD learners. This study provided further challenges for the researchers to consider whether the CSBLS strategy is able to facilitate the achievement of equal literacy competencies a well as knowledge competencies for all students at all school levels. Further research can be carried out more broadly by involving more schools and by introducing variables such as teaching material, e-learning platforms, multiple intelligences, varied topics, social skills, and character learning outcomes.

\section{ACKNOWLEDGEMENT}

The authors appreciates the support of the Dean of Education Faculty of Lambung Mangkurat University and the principals of both participating schools for facilitating this research.

\section{REFERENCES}

Afriana, J. Permanasari, A \& Fitriani, A. (2016). Project based learning integrated to stem to enhance elementary school's students scientific literacy. Jurnal Pendidikan IPA Indonesia, 5(2), 261-267. DOI: 10.15294/jpii.v5i2.5493.

Aiken, L. R. (1985). Three coefficients for analyzing the reliability and validity of ratings. Educational and Psychological Measurement, 45(1), 131-142. https://doi.org/10.1177/001316 4485451012.

Aktamiş, H., Hiğde, E., \& Özden, B. (2016). Effects of the inquiry-based learning method on students' achievement, science process skills and attitudes towards science: A meta-analysis science. Journal of Turkish Science Education, 13(4), 248-261. DOI: 10.12973/tused.10183a.

Ardana, I. M. (2008). Peningkatan kualitas belajar siswa melalui pengembangan pembelajaran matematika berorientasi gaya kognitif dan berwawasan konstruktivis 
[Improving the quality of students' learning through the development of mathematics learning cognitive style-oriented and constructivism-insighted]. Jurnal Penelitian dan Pengembangan Pendidikan, 1(1), 1-14.

Ardianto, D., \& Rubini, B. (2016). Comparison of students' scientific literacy in integrated science learning through model of guided discovery and problem based learning, Jurnal Pendidikan IPA Indonesia, 5(1), 31-37. DOI: 10.15294/jpii.v5i1.5786.

Arends, R. I. (2008). Learning to teach ( $7^{\text {th }}$ Ed.), (H. P. Soetjipto \& S. Mulyantini, Trans.) Yogyakarta: Pustaka Pelajar.

Armstrong, S. J., Peterson E. R., \& Rayner, S. G. (2012). Understanding and defining cognitive style and learning style: A Delphi study in the context of educational psychology. Educational Studies, 38(4), 449-455. https://doi.org/10.1080/ 03055698.2011 .643110 .

Artayasa, I P. Susilo, H., Lestari, U., \& Indriwati, S. E. (2018). The effect of three levels of inquiry on the improvement of science concept understanding of elementary school teacher candidates. International Journal of Instruction, 11(2), 235-248. https://doi.org/10.12973/iji.2018.11216a.

Athuman, J. J. (2017). Comparing the effectiveness of an inquiry-based approach to that of conventional style of teaching in the development of students' science process skills. International Journal of Environmental \& Science Education, 12(8),1797-1816.

Blouin, D., \& Tekian, A. (2018). Accreditation of medical education programs: moving from student outcomes to continuous quality improvement measures. Academic Medicine, 93(3), 377-383. https://doi.org/10.1097/ACM.0000000000001835.

Boccia, M, Piccardi, L., \& Marco M. D. (2016). Does field independence predict visuo-spatial abilities underpinning human navigation? Behavioural evidence. Experimental Brain Research, 234(10), 2799-807. https://doi.org/10.1007/s00221-0164682-9.

Brundiers, K. \& Wiek, A. (2013). Do we teach what we preach? An international comparison of problem- and project-based learning courses in sustainability. Sustainability, 5, 1725-1746. https://doi.org/10.3390/su5041725

Burris, S. \& Garton, B. L. (2007). Effect of instructional strategy on critical thinking and content knowledge: Using problem-based learning in the secondary classroom. Journal of Agricultural Education, 48(1), 106 - 116.

Chen, Y, Liou, S. \& Chen, L (2019). The Relationships among Gender, Cognitive Styles, Learning Strategies, and Learning Performance in the Flipped Classroom, International Journal Of Human-Computer Interaction, 35(5), 395-403, https://doi.org/10.1080/10447318.2018. 1543082.

Dani, D. (2009). Scientific literacy and purposes for teaching science: A case study of lebanese private school teachers. International Journal of Environmental and Science Education, 4(3), 289-299. 
Davis, G. A., (2006). Learning style and personality type preferences of community development extention educators. Journal of Agricultural Education, 47(1), 90-99. https://doi.org/10.5032/jae.2006.01090

Dragos, V. \& Mih, V. (2015). Scientific literacy in school. Procedia-Social and Behavioral Sciences, 209, 167 - 172. https://doi.org/10.1016/j.sbspro.2015.11.273

Drake, K. N. and Long, D. (2009). Rebecca's in the dark: A comparative problem based learning and direct instruction/experiential learning in two $4^{\text {th }}$-grade classrooms. Journal of Elementary Science Education, 21(1), 1-16. https://doi.org/10.1007/ BF03174712.

Ergül, R., Şımşeklı, Y., Çaliş, S., Özdılek, Z., Göçmençelebı, Ş., \& Şanli, M. (2011). The effects of inquiry-based science teaching on elementary school students'science process skills and science attitudes. Bulgarian Journal of Science \& Education Policy, 5(1), 48-68.

Fakhriyah, F., Masfuah, S, Roysa, M., Rusilowati, A., \& Rahayu, S. (2017). Student's science literacy in the aspect of content science. Jurnal Pendidikan IPA Indonesia, 6(1), 81-87. https://doi.org/10.15294/jpii.v6i1.7245

Fitriani, A., Zubaidah, S., Susilo, H., \& Al Muhdhar, M. H. I. (2020). PBLPOE: A learning model to enhance students' critical thinking skills and scientific attitudes. International Journal of Instruction, 13(2), 89-106. https://doi.org/10.29333/ iji.2020.1327a.

Fraenkel, J. R., Wallen, N. E., \& Hyun, H. H. (2012). How to design and evaluate research in education. New York: McGraw-Hill

Hanifah, U., Juniati, D. \& Siswono, T. Y. E. (2018). Students' spatial performance: cognitive style and sex differences. IOP Conf. Series: Journal of Physics: Conf. Series, 947. https://doi.org/10.1088/1742-6596/947/1/012014

Hardianti, T., \& Kuswanto, H. (2017). Difference among levels of inquiry: process skills improvement at senior high school in Indonesia. International Journal of Instruction, 10(2), 119-130. http://www.e-iji.net/dosyalar/iji_2017_2_8.pdf.

Hmelo-Silver, C. E. \& Barrow, H. S. (2006). Goals and strategies of a problem-based learning facilitator. The Interdisciplinary Journal of Problem-Based Learning, 1(1), 2139. https://doi.org/10.7771/1541-5015.1004.

Khafid, M., \& Barokah, S. U. N. (2006). Pengaruh akreditasi sekolah dan persepsi guru mengenai supervisi kepala sekolah terhadap prestasi belajar siswa [The effect of school accreditation and teachers' perceptions of principal supervision on student achievement]. Dinamika Pendidikan, 1(1), 44-62.

Klucevsek, K. M. (2017). The Intersection of Information and Science Literacy. Communications in Information Literacy, 11(2), 354-365. https://doi.org/10.15760/ comminfolit. 2017.11.2.7. 
Komek, E., Yagiz, D., \& Kurt, M. (2015). Analysis according to certain variables of scientific literacy among gifted students that participate in scientific activities at science and art centers1. Journal for the Education of Gifted Young Scientists, III(1), 1-12. https://doi.org/ 10.17478/JEGYS.2015110568.

Malacapay, M. C. (2019). Differentiated instruction in relation to pupils' learning style. International Journal of Instruction, 12(4), 625-638. https://doi.org/10.29333/iji. 2019.12440a.

McBride, D. L., Zollman, D., \& Rebello, N. S. (2010). Method for analyzing students' utilization of prior physics learning in new contexts. Physical Review Special TopicsPhysics Education Research, 6(2), 1-10. https://doi.org/10.1103/PhysRevSTPER. 6.020101

Mefoh, P. C., Nwoke, M. B., Chukwuorji, J. C., Chijioke, A. O. (2017). Effect of cognitive style and gender on adolescents' problem solving ability. Thinking Skills and Creativity, 25(3), 47-52. https://doi.org/10.1016/j.tsc.2017.03.002.

OECD (2019) https://www.oecd.org/pisa/publications/pisa-2018-results.htm. Accessed 14/04/2020.

Peraturan menteri Pendidikan dan Kebudayaan Republik Indonesia (Permendikbud RI) Nomor13 Tahun 2018 tentang Badan Akreditasi Nasional Sekolah/Madrasah dan Badan Akreditasi Nasional Pendidikan Anak Usia Dini dan Pendidikan Nonformal.

Pezzuti, L., Artistico, D., Chirumbolo, A., Picone, L. \& Dowd, S. M. (2014). The relevance of logical thinking and cognitive style to everyday problem solving among older adult. Learning and Individual Difference, 36, 218-223. Doi: http://dx.doi.org /10.1016/j.lindif.2014.07.011.

Rahayu, S. (2017). Promoting the 21st Century Scientific Literacy Skills through Innovative Chemistry Instruction Development of Chemical Education in 21st Century Learning. AIP Conf. Proc. 1911, 020025-1-020025-8, https://doi.org/10.1063/1. 5016018 .

Ratumanan, T. G. (2003). Pengaruh strategi pembelajaran dan gaya kognitif terhadap hasil belajar matematika siswa SLTP di Kota Ambon [Effect of learning strategy and cognitive style to mathematics learning outcome of junior high school students in Ambon City). Jurnal Pendidikan Dasar, 5(1), 1 - 10.

Rubenstein, L. D., Callan, G. L., Neumeister, K. S., \& Ridgley, L. M. (2020). Finding the problem: How students approach problem identification. Thinking Skills and Creativity, 35(1), 100635. https://doi.org/10.1016/j.tsc.2020.100635.

Sholahuddin, A. \& Shadriyah, Y. (2017). Analysis of Students' Process Skills and Chemistry Learning Outcomes. 5th SEA-DR (South East Asia Development Research) International Conference 2017, Advances in Social Science, Education and Humanities Research, 100, 364-369. 
Sholahuddin, A. (2018). Cognitive learning-based strategi to improve conceptual mastery, problem solving ability, and science process skills of elementary school students. Dissertation. (Unpublished). Surabaya: Pascasarjana Unesa.

Sholahuddin, A., Yuanita, L., \& Kardi, S. (2014). @UnESa-GAIn learning strategy for developing the science problem solving ability of elementary school students. Proceeding International Conference on Education Research and Innovation (ICERI). (pp. 407-415). Yogyakarta: UNY.

Sholahuddin, A., Yuanita, L., \& Supardi. (2018). Nurturance Effects of the New Cognitive Style-Based Learning Strategy in Science Learning. Advances in Social Science, Education and Humanities Research, 262, 10-17.

Sholahuddin, A., Yuanita, L., Supardi, Z. I., \& Prahani, B. K. (2020). Applying The Cognitive Style-Based Learning Strategy in Elementary Schools to Improve Students' Science Process Skills. Journal of Turkish Science Education, 17(2), 289-301. https://doi.org/10.12973/tused.10143a

Siregar, A. (2018). Pengaruh akreditasi sekolah dan persepsi guru mengenai supervisi kepala sekolah terhadap kinerja guru SMP Negeri 8 Medan Tahun 2017/2018 [The effect of school accreditation and teacher perceptions of principal supervision on teacher performance at SMP Negeri 8 Medan 2017/2018]. Doctoral Dissertation, Unimed Medan.

Stamovlasis, D., Tsitsipis, G. \& Papagergeou, G. (2010). The effect of logical thinking and two cognitive style on understanding the structure of matter: An analysis with the random walk method. Chemistry Education Research and Practice, 11, 173-181. https://doi.org/10.1039/C005466F

Stepien, W. J., Gallagher, S. A. \& Workman, D. (1993). Problem-based learning for traditional and interdisciplinary classrooms. Journal for the Education of the Gifted, 16(4), 338-357. https://doi.org/10.1177/016235329301600402.

Sugano, S. G. C., \& Nabua, E. B. (2020). Meta-analysis on the effects of teaching methods on academic performance in chemistry. International Journal of Instruction, 13(2), 881-894. https://doi.org/10.29333/iji.2020. 13259a

Tinajero, C, \& Paramo, M. F. (1997). Field dependence-independence and academic achievement: A re-examination of their relationship. British Journal of Educational Psychology, 67(2), 199-212. https://doi.org/10.1111/j.2044-8279.1997.tb01237.x

Tinajero, C., Lemos, S. M., Araujo, M., Ferraces, M. J., \& Paramo, M. F. (2012). Cognitive style and learning strategies as factors which affect academic achievement of Brazilian University Students. Psicologia: Reflexão e Crítica, 25(1), 105-113. https://doi.org/10.1590/S0102-79722012000100013

Vidergor, H. E. Givon, M. \& Mendel, E. (2019). Promoting Future Thinking in Elementary and Middle School Applying the Multidimensional Curriculum Model, Thinking Skills and Creativity, 31(1), 19-30. https://doi.org/10.1016/j.tsc.2018.10.001 
Volkwein, J. F., Lattuca, L. R., Harper, B. J., \& Domingo, R. J. (2007). Measuring the impact of professional accreditation on student experiences and learning outcomes. Research in higher education, 48(2), 251-282. https://doi.org/10.1007/s11162-0069039-y

Wahyuni, S., Indrawati, Sudarti \& Suana,W. (2017). Developing science process skills and problem solving abilities based on outdoor learning in junior high school. Jurnal Pendididkan IPA Indonesia, 6(1), 165-169, doi: 10.15294/jpii.v6i1. 6849.

Wang, H. C. (2014). Seeing the forest and the trees: pictorial complexity, field dependence/independence, and english listening comprehension. English Teaching \& Learning, 38(4), 125-151.

Witkin, H. A., Oltman, P. K., Raskin, E, \& Karp, S. A. (1971). A Manual for the embedded figures test. California: Consulting Psychologists Press, Inc.

Yan, J. H. (2010). Cognitive styles affect choice response time and accuracy. Personality and Individual Differences, 48, 747-75. doi:10.1016/j.paid. 2010.01.021.

Yanto, B. E., Subali, B., \& Suyanto, S. (2019). Improving students' scientific reasoning skills through the three levels of inquiry. International Journal of Instruction, 12(4), 689-704. https://doi.org/10.29333/iji.2019.12444a

Zhang, L. (2010). Field-dependence/independence: cognitive style or perceptual ability?-Validating against thinking styles and academic achievement. Personality and Individual Differences, 37, 1295-1311. doi:10.1016/ j.paid.2003.12.015.

Zion, M., \& Mendelovici, R. (2012). Moving from structured to open inquiry: Challenges and limits. Science Education International, 23(4), 383-399.

Zulnika, Z. (2017). Pengaruh akreditasi sekolah dan kinerja guru terhadap mutu pembelajaran siswa SMP Negeri di Kecamatan Kopang [The effect of school accreditation and teacher performance on the quality of learning of State Junior High School students in Kopang District]. Jurnal Ilmiah Profesi Pendidikan, 2(2), 222-227. 